\title{
The association of HBV with immigrant subjects
}

\author{
Temur $\mathrm{A}^{1}$, Dülger AC ${ }^{2}$ \\ Biology Department, Yuzuncuyil University, Van, Turkey. temurat@yahoo.com
}

Text in PDF www.elis.sk.

Dear Editor-in-Chief,

An estimated 9 million Syrians have fled their homes since the outbreak of civil war in March 2011, taking refuge in neighbouring countries or within Syria itself. According to the United Nations High Commissioner for Refugees (UNHCR), over 3 million have fled to Syria's immediate neighbours Turkey, Lebanon, Jordan and Iraq. As the turmoil increased and the humanitarian conditions in Syria worsened, Syrians started to migrate in huge numbers. Syrian immigrants are mostly located in Hatay, Kilis, Gaziantep and Sanliurfa, which are all border provinces in Turkey. Over one million Syrian refugees have also registered as refugees in southern part of Turkey (1).

Chronic liver diseases are important causes of morbidity and mortality all over the world and the Mediterranean basin is no exception. According to the World Health Organization, of the estimated 400 million persons infected with hepatitis B infection ( HBV) worldwide (2). In fact, the "the hepatitis B belt" originates from the Far East and extends to the Middle East encompassing the Iranian border of Turkey (3).

Chronic HBV infection is also a disease of poverty, linked to poor health conditions and lack of infrastructure. Social turmoils and wars are also independent risk factors for spreading of HBV infection, which is associated with an increased risk of death from cirrhosis as well as hepatocellular carcinoma. Authors always concluded that a key driver of the hepatitis $\mathrm{B}$ epidemic is disturbed health conditions due to immigration $(4,5,6)$.

An association of HBV with immigrant subjects has been reported in many studies (7), but data in Syrian refugees has never been studied. Our goal was therefore to examine HBV prevalence in Syrian refugees who are resident in the Syrian border of Turkey, city of Kilis. A total of 251 consecutive Syrian refugee patients (130 female; aged 18-75 years) were seen from September 2013 to October 2014 and were studied via individual chart review using a case report form. HBV infection was defined by positive hepatitis B surface antigen (HBs Ag) or HBV DNA PCR. Control subjects were selected from patients seeking primary care at gastroenterology clinic of Yuzuncuyil University in Van city, where located in the Iranian border of Turkey. Of these 251 patients, 28 patients (11.1 \%; 13 female) had positive HBs Ag. Of the 1062 screened control subjects (550 female), 61 (5.7 \%; 31 female) patients tested positive for HBs antigen. There were no statistically significant differences with regard to age and sex profile between refugees and control subjects. There was a

${ }^{1}$ Biology Department, Yuzuncuyil University, Van, Turkey, and ${ }^{2}$ Gastroenterology Department, Medical School, Yuzuncuyil University, Van, Turkey,

Address for correspondence: A. Temur, Biology Department, Yuzuncuyil University, Van, Turkey. statistically significant difference between Syrian immigrants and naive Turkish citizens ( $\mathrm{p}<0.005)$.

In the current study, HBV prevalence in Syrian refugees seeking routine primary care was $11.1 \%$, which was over double the prevalence for native Turkish citizens at $5.7 \%$. Prevalence of hepatitis B in the general Turkish population is close to $4 \%$ and Turkey is a country with intermediate endemicity for hepatitis B (8). The high prevalence of HBV in Syrians may be due to higher prevalence of HBV in their birth regions in Syria.

Important limitations of the current study include an inadequate sample size and risk factors of HBV infection, such as immigration period of the refugees. Despite these limitations, we concluded that HBV screening among Syrian refugees represents a potentially useful strategy to prevent HBV infection. Our findings have also important implications for estimates of HBV incidence in Syrian immigrants. The real number of hepatitis B cases may be still far higher than that. Immigrants from Syria are at higher risk of HBV infection and should be screened for HBV regardless of their exposure risk profile.

\section{References}

1. www. data.unher.org/syrianrefugees/syria.php.

2. Robotin M, Patton Y, Kansil M, Penman A, George J. Cost of treating chronic hepatitis B: comparison of current treatment guidelines. Gastroenterol 2012;18 (42): 6106-6113.

3. Kemal Celen M, Tekin Koruk S, Aygen B et al. The characteristics of patients with chronic hepatitis B in Turkey. Med Glas (Zenica) 2014; 11: 94-98.

4. Ganem D, Prince AM. Hepatitis B virus infection - natural history and clinical consequences. N Engl J Med 2004; 350 (11): 1118-1129.

5. Rossi C, Shrier I, Marshall L, Cnossen S, Schwartzman K, Klein MB, Schwarzer G, Greenaway C. Seroprevalence of chronic hepatitis B virus infection and prior immunity in immigrants and refugees: a systematic review and meta-analysis. PLoS One 2012; 7 (9): e44611.

6. Rossi C, Schwartzman K, Oxlade O, Klein MB, Greenaway C. Hepatitis B screening and vaccination strategies for newly arrived adult Canadian immigrants and refugees: a cost-effectiveness analysis. PLoS One 2013; 8 (10): e78548

7. Chai SJ, Davies-Cole J, Cookson ST. Infectious disease burden and vaccination needs among asylees versus refugees, district of columbia. Clin Infect Dis 2013; 56 (5): 652-658.

8. Ay P, Torunoglu MA, Com S, Çipil Z, Mollahaliloğlu S, Erkoc Y, Dilmen U. Trends of hepatitis B notification rates in Turkey, 1990 to 2012. Euro Surveill 2013; 18 (47).

Received November 15, 2017. Accepted November 27, 2017. 